\title{
Does the earnings quality matter? Evidence from a quasi-experimental setting
}

\author{
Giulia Baschieri ${ }^{\mathrm{a}}$, Andrea Carosi ${ }^{\mathrm{b}}$, Stefano Mengoli ${ }^{\mathrm{c}, *}$ \\ a Ca' Foscari University of Venice, Department of Management, San Giobbe, Cannaregio 873, 30121, Venice, Italy \\ ${ }^{\mathrm{b}}$ University of Sassari, Department of Economics and Business, 25 Via Muroni, 07100, Sassari, Italy \\ c University of Bologna, Department of Management, Via Capo di Lucca 34, 40126, Bologna, Italy
}

\section{A R T I C L E I N F O}

\section{Article history:}

Received 2 February 2016

Revised 26 May 2016

Accepted 25 July 2016

Available online 28 July 2016

\section{JEL classification :}

M41

G11

G12

\section{Keywords:}

Earnings quality

Accounting information

Local Home Bias

\begin{abstract}
A B S T R A C T
Investor preference for local stocks provides a quasi-experimental setting to investigate whether the market rewards firms that comply with generally accepted accounting principles. We show firms with low earnings quality trade at a premium compared to firms in compliance with accounting principles; the difference in values is greater when the role of local investor over-trading is stronger in stock price-formation, in other words for the more isolated firms. The value of the information not conveyed to the market through accounting disclosure accounts for $30 \%$ of the market-to-book. Results are robust to earnings quality definition, and show while non-local investors are sensitive to the quality of accounting information, local and better-informed investors are not. Overall, accounting quality matters.
\end{abstract}

(c) 2016 Published by Elsevier Inc.

\section{Introduction}

The global financial crisis of 2007-2008 highlighted a fundamental need for transparency in corporate practices (e.g., Arnold, 2009; Barth and Landsman, 2011). For more than 40 years, the literature has been calling for more informative accounting disclosures and increased emphasis on detecting earnings management and fraudulent reporting (e.g., Chung et al., 2009; Dechow et al., 2010; Kothari, 2001; Lahr, 2014). Interestingly, research on compliance does not provide a clear picture on the relationship between firms' reporting quality and financial consequences, and whether the market rewards compliance with accounting principles is also unclear (e.g., Bhattacharya et al., 2003; Chan et al., 2006; Core et al., 2008; Francis et al., 2005; Morricone et al., 2009). Francis et al., (2005) show that reporting quality matters since investors price securities based on their awareness of accruals quality. On the other hand, Core et al., (2008) find no evidence that accruals quality is a priced risk factor and Lev (1989) suggests only a weak correlation between stock market returns and earnings disclosure, concluding that 'earnings manipulation is prevalent; but, except for egregious cases, it is hard to detect and prosecute' (Lev, 2003, p. 48).

This paper exploits the quasi-experimental setting provided by investor tendency to overinvest in geographically proximate, or local stocks (the so-called Local Home Bias) (e.g., Coval and Moskowitz, 1999; Cumming and Johan, 2006) to investigate whether the market rewards firms that comply with accounting principles. The Local Home Bias is double-faced in

\footnotetext{
* Corresponding author.

E-mail address: stefano.mengoli@unibo.it (S. Mengoli).
} 
nature. On one side, it stems from information advantages on local firms: proximity gives investors greater value-relevant information about the local firms, leading investors to prefer local firms over non-local firms (e.g., Coval and Moskowitz, 2001; Cumming and Dai, 2010; Ivković and Weisbenner, 2005). On the other hand, behavioural factors also come into play (e.g., Grinblatt and Keloharju, 2001; Levis et al., 2015; Shan and Gong, 2012). For instance, Grinblatt and Keloharju (2001) provide evidence that shareholders are more likely to trade in local stocks when the issuing firm CEO communicates in the same language as the investor or shares the same cultural background. This investor preference for local stocks even affects corporate market values (e.g., Baschieri et al., 2015; Hong et al., 2008; Korniotis and Kumar, 2013b). In fact, since a portion of local investor wealth will be invested in local equity, the lower the number of local firms, the higher the amount of local wealth invested in each local firm. As a result, isolated firms trade at a premium compared to non-isolated firms. In addition, as they are more informed, local investors ask for lower returns on local firms. Therefore, with respect to clustered firms the isolated firms benefit from a larger clientele of local investors asking for lower returns, and ultimately have higher market values.

The investor preference for local equity provides a quasi-experimental setting to test whether the market rewards compliance with accounting principles as the Local Home Bias disentangles the accounting information, or the information available to both local and non-local investors, from the local information, which is only available to local investors. Firms with full disclosure and high earnings quality, or firms that fully comply with accounting principles, are identical to both local and non-local investors, causing the information advantage for local investors to vanish. On the other hand, firms with partial disclosure and low earnings quality, or opaque firms, allow local investors to gain a valuable informational advantage as partial disclosure increases the information risk ${ }^{1}$ for non-local investors. Therefore, they tend to shy away from opaque firms or, ask for higher returns in compensation for larger information asymmetries, while local investors move towards opaque local firms, trying to exploit their information advantage. This turn of events creates an apparent paradox, where firms with low earnings quality trade at a premium compared to firms with high earnings quality; the difference in firm values is greater when the role of local investor over-trading is stronger in stock price-formation, in other words for the more isolated firms. Therefore, we argue that the more a firm is isolated from other listed firms, the more a firm with low earnings quality trades at a premium compared with a firm with high earnings quality. The differential market value between low and high earnings quality firms is the value of the information that is not conveyed to the market through the accounting disclosure, or, in other words, it is the value of the accounting information.

Investment in local equity is not only driven by superior information on local firms (e.g., Coval and Moskowitz, 2001; Ivković and Weisbenner, 2005), but is also enhanced by the familiarity investors feel towards nearby companies (e.g., Grinblatt and Keloharju, 2001; Huberman, 2001), and our results might be affected by this behaviour. Within low and high earnings quality firms, we overcome this issue by further distinguishing under- from over-performing stocks (e.g., stocks with positive Jensen's alpha in the next 3 years). In line with the literature (e.g., Korniotis and Kumar, 2013a), we assume that investors with superior information are able to distinguish local under- from local over-performing stocks and pursue long positions only on local over-performing stocks (ignoring local under-performing stocks). On the other hand, when investors show a preference for local stocks based on feelings of familiarity with nearby firms, they are expected to be equally attracted to both under- and over-performing local stocks. In this case, over-performing firms are predicted to trade at a premium compared with under-performing firms and the difference in market values tells us to what extent the investor preference for local stocks is indeed driven by superior information. To the extent that the empirical patterns of high and low earning quality firms are unchanged across under- and over-performing stocks, our results are not affected.

To test our conjectures we analysed the Italian firms listed on the Milan Stock Exchange (MSE) over the period 19992011. The MSE ranks at the top among informationally opaque financial markets (e.g., Bhattacharya et al., 2003; Leuz et al., 2003) and uncertain legality in Italy is widely recognised (e.g. Cumming and Zambelli, 2013; Bigelli and Mengoli, 2011) with Leuz et al., (2003) classifying Italy fourth out of 31 countries for earnings management. Although Consob (the Italian equivalent of US SEC) has improved disclosure requirements for firms listed on the MSE (e.g., segment information disclosure in compliance to IAS 14) with legislative decree 58/1998 (Consolidated Law on Finance), the regulations give no details about how or what quantity of information should be disclosed. There is no clear sanction for companies that do not comply and as a result, disclosure by Italian firms is limited due to disclosure-related costs and the risk of providing useful information to competitors (Prencipe, 2004). Therefore, Italy represents an ideal research setting for investigating value implications of firm compliance with accounting principles (Mengoli et al., 2009; Pazzaglia et al., 2013).

In line with the literature (e.g. Hong et al., 2008), we find that corporate market values increase the more the issuing firm is isolated from the other listed firms. Furthermore, we find over-performing firms trade at a premium compared with under-performing firms, and the wedge between the market values increases with the extra-performance period. Overall this evidence is consistent with local investor superior information on local stocks. When low vs. high earnings quality firms are investigated, results are as expected. We use a wide range of market- and accounting-based measures to proxy for firm earnings quality: in all cases the more the firm is isolated from the other listed firms, the more the firm with low earnings quality trades at a premium compared to the firm with high earnings quality. In addition, the market value of low earnings quality firms is larger for over-performing than for under-performing firms, and increases with the extra-

\footnotetext{
${ }^{1}$ For instance, in Bertinetti and Mantovani (2012) the information risk originates from the timing of the information spreading in the market, the errors in the information, and the ways the information is transmitted to the market. Huang and Cheng (2013) define the information risk as the ambiguity of the information possessed by market participants.
} 
performance period. This evidence shows local investors profitably exploit the locally available information by investing in opaque firms with positive future risk-adjusted performance. The value of the local information drops with the earnings quality and accounts for approximately $30 \%$ of the market-to-book: remarkably, this represents the value of the information not conveyed to the market through the accounting disclosure.

We first add to the literature on the relation between the quality of reporting and capital market consequences. In fact, we show that compliance with accounting principles matters. Yet, while extant literature shows either the existence of a positive relation (e.g., Francis et al., 2005) or the lack of a relation (e.g., Core et al., 2008) between accruals quality and corporate market valuation, we find a negative relation between earnings quality and investor trading pattern when taking a local perspective of analysis. Our results suggest investors evaluate the earnings quality according to their location and this has pricing implications. In fact, the quality of accounting information seems to be irrelevant when local investors evaluate stocks. On the other hand, the firm earnings quality matters in order to define the value of the information advantage local investors have compared to the rest of the market. Ultimately, the proportion of local vs. non-local investors defines the effect of earnings quality on market values.

Differently from previous research, we focus on compliance value implications consistent with active investors exploiting the local information advantage available to them. As such, we add a new perspective to the literature addressing the value of firm disclosure in attracting investors and signalling the firm's quality to the market (e.g., Al Jifri and Citron, 2009). Yet, unlike previous studies, our results suggest firms might voluntarily decide not to face the costs of full information disclosure due to the value enhancing effect of local investor trading, based on recognition of the firm's fair value.

Overall, our results show that firm opacity leverages the bias of investors to invest locally. This evidence is consistent with recent behavioural models (e.g., Daniel et al., 1998, 2001; Hirshleifer, 2001) and previous evidence (e.g., Kumar, 2009) of a positive bias-uncertainty relation. For instance, Kumar (2009) documents that 'during times of greater market-level uncertainty, investors exhibit a stronger preference for familiar stocks and tilt their portfolios more toward domestic and local stocks' (p. 1377). Our findings are related to this strand of literature showing a positive relation between the Local Home Bias and the level of uncertainty; unlike other studies, we address this relationship at the firm-level rather than at market-level.

The remainder of the paper is structured as follows. Section 2 illustrates the sample and the methodology. Section 3 investigates the over- and under-performing firms. Section 4 presents evidence on low and high earnings quality firms. Section 5 concludes.

\section{Methodology}

\subsection{Data and sample selection}

We investigated several data sources: (i) the databases provided by Consob (i.e., the equivalent of US SEC) for our sample; (ii) Osiris (Bureau Van Dijk database) and company annual reports for data on firm location; (iii) the archives provided by Borsa Italiana S.p.A. (the MSE's managing company) for information on securities listings; (iv) the electronic archive of the financial newspaper Il Sole 24Ore for press coverage; (v) the investment guide Il Calepino dell' Azionista for firm age; (vi) the databases of ISTAT (Italian Institute of Statistics) and Centro Studi Unioncamere (the research centre of regional Chambers of Commerce) for information on wealth distribution; and (vii) Datastream and Worldscope (Thompson Financial) for all other accounting and financial information. Finally, Google Maps allowed us to collect the geographic coordinates (i.e., latitude and longitude) of each sampled firm headquarters.

Our initial sample consists of 3020 firm-year observations for firms issuing common stock on the MSE over the period 1999-2011. From the initial sample, we exclude observations (i) of non actively traded stocks, (ii) with ROE out of a range of plus one and minus one, (iii) not headquartered in Italy, and (iv) on financial firms (SIC 6000-6999). The resulting unbalanced panel data set consists of 2240 firm-year observations and is our final sample.

\subsection{Methodology and variables definition}

The logarithmic transformation of the market-to-book ratio (LN(MARKET-TO-BOOK)) is our left-hand side variable, while we proxy the level of firm isolation and hence the firm Local Home Bias through the variable I_FIRM (Baschieri et al., 2015). I_FIRM is the Johnson and Zimmer (1985) spatial dispersion index: it is based on point-to-point individual distances and computed for every firm-year observation on the spatial distribution of all other listed firms. The expected value of I_FIRM is approximately two: values lower than two reveal a low concentration of listed firms around the firm headquarters, while values higher than two indicate a higher concentration of listed firms around the firm headquarters. Therefore, a low value of I_FIRM represents isolated firms and indicates high Local Home Bias. Consistent with previous evidence, we expect the MARKET-TO-BOOK to be negatively affected by I_FIRM: the magnitude of this relation is the Local Home Bias effect, that is the portion of corporate market value related to the investor preference for local equity. As a robustness check, we re-run our analysis using the Hong et al., (2008)' RATIO variable as proxy for the Local Home Bias, with unchanged results (not 
reported). ${ }^{2}$ Finally, as in Baschieri et al., (2015) and Hong et al., (2008), when we run our regressions we exclude financial firms, yet keep these observations when computing I_FIRM and RATIO.

We distinguish future risk-adjusted under- and over-performing firms. Firm risk-adjusted extra-performance is estimated by Jensen's alpha (Jensen, 1968) from an expanded index model regression (ALPHA), and upon a minimum of 6 months of weekly observations (Hutton et al., 2009). Over-performing firms are firms with positive ALPHA, while under-performing firms are firms with negative $A L P H A\left(A L P H A^{+}\right.$vs. $\left.A L P H A^{-}\right)$. We consider three progressively stronger and nested definitions of future over- and under-performing firms. In particular, we introduce three interacting dummy variables detecting firms with positive (negative) ALPHA in the prospective year only (1yALPHA ${ }^{+}$vs. $\left.1 y A L P H A^{-}\right)$, in both the next 2 years $\left(2 y A L P H A^{+}\right.$ vs. $2 y A L P H A^{-}$), and in each of the next 3 years $\left(3 y A L P H A^{+}\right.$vs. $\left.3 y A L P H A^{-}\right)$. We expect the isolated $A L P H A^{+}$firms to trade at a premium compared with isolated $A L P H A^{-}$firms, and the magnitude of this relation increases with the Local Home Bias. In addition we predict this effect to increase as the over-performing period continues, i.e. shifting from $1 y A L P H A^{+}$to $3 y A L P H A^{+}$.

We further distinguish low and high earnings quality firms. The literature provides a wide range of measures for earnings quality (EQ), and the selection of the most appropriate is definitely not trivial (e.g., Dechow et al., 2010; Ecker et al., 2013). Yet, lack of transparency is associated with higher $\mathrm{R}^{2} \mathrm{~s}$, indicating little revelation of firm-specific information (e.g., Hutton et al., 2009; Jin and Myers, 2006). Consistent with measurement issues, we implement several alternative proxies for EQ. We use three market-based measures of EQ: (i) the negative skewness of beta-adjusted weekly residual returns divided by the cubed standard deviation (EQ1 MARKET) (e.g., Chen et al., 2001; Jin and Myers, 2006); (ii) the difference of downside frequencies and upside frequencies of the firm-specific weekly residual returns exceeding $\mathrm{k}$ standard deviations above and below the mean, with k chosen to generate frequencies of $0.01 \%$ in the normal distribution (EQ2 MARKET) (e.g., Hutton et al., 2009; Jin and Myers, 2006); and (iii) the idiosyncratic risk or firm-specific volatility as defined by the logistic transformation of $\mathrm{R}^{2}$ (EQ3 MARKET) (e.g., Hutton et al., 2009; Morck et al., 2000). We also proxy EQ from accounting data using discretionary accruals (e.g., Christensen et al., 2013). We estimate discretionary accruals according to Dechow et al., (1995) (DISC ACC). We then proxy EQ with: (iv) the absolute value of DISC ACC (EQ1 ACCOUNTING) (e.g., Dechow et al., 1995), and v) the 3 years moving sum of EQ1 ACCOUNTING (EQ2 ACCOUNTING) (e.g., Hutton et al., 2009). ${ }^{3}$ All measures are inversely related to EQ as, for instance, an increase in EQ1 MARKET means the stock is more "crash prone". Therefore, high earnings quality firms are firms with EQ below the cross-sectional median, and low earnings quality firms are firms with EQ above the cross-sectional median (HIGH EQ vs. LOW EQ). We expect to see a direct relationship between an increase in firm isolation and the LOW EQ firms trading at a premium compared to HIGH EQ firms.

In the multivariate analysis, we include a wide range of control variables. In particular we control for (with predictions):

(+) local investor risk-tolerance (I_INCOME). I_INCOME is the Johnson and Zimmer (1985) spatial dispersion index computed for every firm-year observation on the spatial distribution of household disposable income. A high value of I_INCOME indicates a higher concentration of investor wealth around the firm headquarters. As in Aabo et al., (2013), Baschieri et al., (2015), and Hong et al., (2008), we assume local investor risk-tolerance proportional to the local wealth, and predict a positive relation between MARKET-TO-BOOK and I_INCOME;

$(+)$ current equity profitability $(R O E)$ : more profitable firms are expected to benefit from a higher market valuation, and a positive relation between $R O E$ and MARKET-TO-BOOK is predicted (e.g., Bagella et al., 2000);

$(+)$ firm future growth opportunities (RED-TO-SALES): superior growth prospects drive higher stock prices, and a positive relation with MARKET-TO-BOOK is expected (e.g., Hall and Oriani, 2006);

(-) firm size, defined by total asset (LN(1+FIRM SIZE)): small firms are characterized by larger information asymmetries than large firms, and a negative relation with MARKET-TO-BOOK is predicted (e.g., van Dijk, 2011);

(-) firm age, defined by the number of years of a firm's life since foundation (LN(1+FIRM AGE)): less information is usually available for younger firms which are therefore riskier than older firms, and a negative relation with MARKET-TO-BOOK is expected (e.g., Keloharju and Kulp, 1996);

(+) firm press coverage, defined by the yearly number of newspaper articles reporting the firm name $(L N(1+P R E S S$ COVERAGE)). High media coverage is expected to disclose valuable information about the firm, and a positive relation with MARKET-TO-BOOK is predicted (e.g., Birz and Lott, 2011).

In addition, we include in all regressions (not shown) a dummy variable which equals one if the company does not report R\&D expenditure $(R E D)$ and zero otherwise (Chan et al., 2001), a set of four-digit SIC industry dummies, a set of exchange segment listing dummies, and a set of year dummies. Finally, we control for any possible cross-sectional and time-series correlation by clustering standard errors both at firm- and year-level, consistent with Petersen (2009).

Table 1 reports descriptive statistics for sampled firms, while Table A.1 in the Appendix provides detailed definitions of the variables here employed.

\footnotetext{
${ }^{2}$ Hong et al. (2008)'s key variable is the ratio (RATIO) of the equity book value of all listed firms headquartered within the same Census region (i.e. the local supply of stocks) and the disposable income of all households living in the region (i.e. the local demand for stocks).

${ }^{3}$ For robustness purposes we re-run our analysis using alternative definitions both for discretionary accruals and EQ. In particular, we also estimate discretionary accruals according to the method used in Ashbaugh et al. (2003) (REDCA) and we further define EQ with: vi-viii) the 3(5)(7) years moving standard deviation of REDCA (EQ3(4)(5) ACCOUNTING) (e.g., Chaney et al., 2011), and ix-x) the $\mathrm{R}^{2}$ (Adjusted $\mathrm{R}^{2}$ ) from the expanded index model regression of weekly returns (R-SQUARED and ADJUSTED R-SQUARED) (e.g., Hutton et al., 2009; Jin and Myers, 2006). In all the cases, results (not reported) are unchanged.
} 
Table 1

Summary statistics.

\begin{tabular}{|c|c|c|c|c|}
\hline & Mean & Median & 25-tile & 75-tile \\
\hline \multicolumn{5}{|c|}{ Firm characteristic } \\
\hline MARKET-TO-BOOK & 2.28 & 1.65 & 1.14 & 2.52 \\
\hline I_FIRM & 2.93 & 3.09 & 1.72 & 3.86 \\
\hline I_INCOME & 2.06 & 2.18 & 1.90 & 2.27 \\
\hline ROE & $5.05 \%$ & $7.44 \%$ & $1.07 \%$ & $13.46 \%$ \\
\hline$R E D-T O-S A L E S$ & $0.49 \%$ & $0.00 \%$ & $0.00 \%$ & $0.00 \%$ \\
\hline FIRM SIZE & 11,433 & 507 & 169 & 3617 \\
\hline FIRM AGE & 48 & 29 & 14 & 78 \\
\hline PRESS COVERAGE & 32 & 14 & 8 & 27 \\
\hline \multicolumn{5}{|c|}{ Firm over-performance } \\
\hline ALPHA & $0.12 \%$ & $0.07 \%$ & $-0.27 \%$ & $0.44 \%$ \\
\hline 1yALPHA ${ }^{+}$ & 0.56 & 1.00 & 0.00 & 1.00 \\
\hline $2 y A L P H A^{+}$ & 0.34 & 0.00 & 0.00 & 1.00 \\
\hline 3yALPHA & 0.21 & 0.00 & 0.00 & 0.00 \\
\hline \multicolumn{5}{|c|}{ Firm earnings quality } \\
\hline EQ1 MARKET & $-15,347$ & -5935 & $-19,539$ & 747 \\
\hline EQ2 MARKET & -0.25 & 0.00 & -1.00 & 0.00 \\
\hline EQ3 MARKET & 1.33 & 1.25 & 0.57 & 1.99 \\
\hline EQ1 ACCOUNTING & 0.07 & 0.04 & 0.02 & 0.08 \\
\hline EQ2 ACCOUNTING & 0.21 & 0.15 & 0.09 & 0.25 \\
\hline
\end{tabular}

This table reports the summary statistics on firm characteristics. The sample consists of 2240 observations on Italian nonfinancial firms traded on the MSE over the period 1999-2011. All variables are defined as in the appendix.

\section{Firm over-performance and the Local Home Bias}

In this section, we test the significance of the relations between LN(MARKET-TO-BOOK) and I_FIRM across future riskadjusted over- $\left(A L P H A^{+}\right)$and under-performing $\left(A L P H A^{-}\right)$firms. We expect a negative relation between I_FIRM and MARKETTO-BOOK. In addition, we predict this effect to be larger in future over-performing than in under-performing firms (i.e., $\beta_{1}$ $<\beta_{2}$ ). Finally, we expect the effect of I_FIRM to increase shifting from firms with positive ALPHA in the prospective year only $\left(1 y A L P H A^{+}\right)$to firms over-performing in each of the next 3 years $\left(3 y A L P H A^{+}\right)$. Table 2 shows the results.

As expected, the effect of I_FIRM on LN(MARKET-TO-BOOK) is negative and significant (Model 1: $\beta_{1}=-0.087, p$ value $<0.05$ ). When we distinguish over- and under-performing firms, results are as predicted. In fact, the relation between I_FIRM and MARKET-TO-BOOK remains negative and statistically significant. Furthermore, the effect of I_FIRM is stronger both in magnitude and in statistical significance in over- than in under-performing firms (e.g., Model 4: $\beta_{1}=-0.143, p$ value $<0.01 ; \beta_{2}=-0.074, p$-value $<0.10 ; F$-Test $\beta 1=\beta 2=2.88, p$-value $<0.10$ ), meaning that, the more the firm is isolated, the more a firm with a positive future risk-adjusted performance trades at a premium compared to a future under-performing firm. Looking at the number of years the firm over-performs, as predicted the relation between I_FIRM and MARKET-TO$B O O K$ is stronger the longer the future over-performing period is, that is shifting from $1 y A L P H A^{+}$(Model 2) to $3 y A L P H A^{+}$ (Model 4). For instance, the effect of I_FIRM in firms with positive ALPHA in each of the next 3 years is 52\% higher than in firms over-performing in the prospective year only. In addition, the dummy variables detecting over-performing firms (i.e., $1 y A L P H A^{+}, 2 y A L P H A^{+}$and $3 y A L P H A^{+}$) are not significant in explaining the MARKET-TO-BOOK, suggesting non-local investors fail in detecting firms with positive ALPHA. Finally, the pattern of the control variables is as expected.

Our results suggest that the preference for local stocks is related to the information advantage investors possess about local firms: investors pick local isolated over-performing firms which eventually trade at a premium compared to local isolated under-performing firms. As further evidence, the difference in market values between isolated over- and under-performing firms increases with the over-performing period, that is when the local information advantage is more substantial and valuable. Yet, although lower in magnitude, the Local Home Bias effect detected in isolated under-performing firms support that even a behavioural component of investor preference for local stocks is in play. Economically, a measure of local investor information advantage can be inferred by considering the average sampled over-performing firm, for which MARKET-TO-BOOK is 1.65 , I_FIRM is 3.09 and $3 y A L P H A^{+}$is 1 . Our findings imply that, all other things being equal, 0.94 of MARKET-TO-BOOK is attributable to I_FIRM. In fact, $0.442(0.442=0.143 \times 3.09)$ is the estimated $L N($ MARKET-TO-BOOK) attributable to I_FIRM, and $1.556\left(1.556=\mathrm{e}^{(0.442)}\right)$, is the corresponding estimated MARKET-TO-BOOK, which is $0.94(0.9428=1.556 / 1.65)$ of MARKETTO-ВООК. The same estimate for the average sampled under-performing firm $\left(3 y A L P H A^{-}=1\right)$ is about 0.76 , meaning that the MARKET-TO-BOOK of isolated firms over-performing in each of the next 3 years is $18 \%$ higher than the MARKET-TO$B O O K$ of isolated firms with negative Jensen's alphas in the same period. This difference in value is entirely attributable to the superior information local investors possess about nearby firms. Similar but smoothed dynamics hold for firms over-(under-)performing in the next 2 and 1 years. 
Table 2

The Local Home Bias and the firm over-performance.

\begin{tabular}{|c|c|c|c|c|c|}
\hline \multirow{2}{*}{$\frac{\text { Dependent variable }}{\text { Independent variables }}$} & & \multicolumn{4}{|c|}{ LN(MARKET-TO-BOOK) } \\
\hline & & (1) & (2) & (3) & (4) \\
\hline Constant & & $\begin{array}{c}0.443 \\
(0.99)\end{array}$ & $\begin{array}{c}0.458 \\
(1.05)\end{array}$ & $\begin{array}{r}0.451 \\
(1.03)\end{array}$ & $\begin{array}{r}0.415 \\
(0.94)\end{array}$ \\
\hline I_FIRM & & $\begin{array}{l}-0.087^{* *} \\
(-2.08)\end{array}$ & & & \\
\hline I_FIRM*1yALPHA ${ }^{+}$ & $\beta_{1}$ & & $\begin{array}{l}-0.094^{* *} \\
(-2.26)\end{array}$ & & \\
\hline I_FIRM*1yALPHA ${ }^{-}$ & $\beta_{2}$ & & $\begin{array}{l}-0.085^{*} \\
(-1.89)\end{array}$ & & \\
\hline $1 y A L P H A^{+}$ & & & $\begin{array}{l}-0.100 \\
(-1.19)\end{array}$ & & \\
\hline I_FIRM*2yALPHA ${ }^{+}$ & $\beta_{1}$ & & & $\begin{array}{l}-0.105^{* *} \\
(-2.38)\end{array}$ & \\
\hline I_FIRM*2yALPHA ${ }^{-}$ & $\beta_{2}$ & & & $\begin{array}{l}-0.083^{*} \\
(-1.84)\end{array}$ & \\
\hline $2 y A L P H A^{+}$ & & & & $\begin{array}{l}-0.052 \\
(-0.44)\end{array}$ & \\
\hline I_FIRM*3yALPHA ${ }^{+}$ & $\beta_{1}$ & & & & $\begin{array}{l}-0.143^{* * *} \\
(-3.01)\end{array}$ \\
\hline I_FIRM*3yALPHA ${ }^{-}$ & $\beta_{2}$ & & & & $\begin{array}{l}-0.074^{*} \\
(-1.69)\end{array}$ \\
\hline $3 y A L P H A^{+}$ & & & & & $\begin{array}{c}0.066 \\
(0.47)\end{array}$ \\
\hline I_INCOME & & $\begin{array}{l}0.420^{* * * *} \\
(2.62)\end{array}$ & $\begin{array}{l}0.430^{* * * *} \\
(2.68)\end{array}$ & $\begin{array}{l}0.423^{* * *} \\
(2.61)\end{array}$ & $\begin{array}{l}0.419^{\text {**** }} \\
(2.59)\end{array}$ \\
\hline$R O E$ & & $\begin{array}{c}0.373^{*} \\
(1.82)\end{array}$ & $\begin{array}{l}0.421^{\text {*** }} \\
(2.21)\end{array}$ & $\begin{array}{l}0.403^{* *} \\
(2.02)\end{array}$ & $\begin{array}{l}0.399^{* * *} \\
(1.98)\end{array}$ \\
\hline RED-TO-SALES & & $\begin{array}{r}1.725 \\
(1.34)\end{array}$ & $\begin{array}{c}1.798 \\
(1.41)\end{array}$ & $\begin{array}{r}1.701 \\
(1.34)\end{array}$ & $\begin{array}{c}1.594 \\
(1.23)\end{array}$ \\
\hline$L N(1+F I R M ~ S I Z E)$ & & $\begin{array}{l}-0.074^{* *} \\
(-2.18)\end{array}$ & $\begin{array}{l}-0.074^{* *} \\
(-2.24)\end{array}$ & $\begin{array}{l}-0.073^{* *} \\
(-2.23)\end{array}$ & $\begin{array}{l}-0.072^{* *} \\
(-2.19)\end{array}$ \\
\hline$L N(1+F I R M A G E)$ & & $\begin{array}{l}-0.102^{* * *} \\
(-3.66)\end{array}$ & $\begin{array}{l}-0.100^{\text {**** }} \\
(-3.56)\end{array}$ & $\begin{array}{l}-0.100^{\text {**** }} \\
(-3.53)\end{array}$ & $\begin{array}{l}-0.099^{* * *} \\
(-3.52)\end{array}$ \\
\hline LN $(1+P R E S S$ COVERAGE) & & $\begin{array}{l}0.255^{* * *} \\
(5.37)\end{array}$ & $\begin{array}{l}0.253^{* * *} \\
(5.32)\end{array}$ & $\begin{array}{l}0.253^{* * * *} \\
(5.40)\end{array}$ & $\begin{array}{l}0.251^{* * * *} \\
(5.20)\end{array}$ \\
\hline Dummy industry & & YES & YES & YES & YES \\
\hline Dummy exchange segment & & YES & YES & YES & YES \\
\hline Dummy year & & YES & YES & YES & YES \\
\hline Number of observations & & 1303 & 1303 & 1303 & 1303 \\
\hline $\mathrm{R}^{2}$ - adjusted & & 0.426 & 0.434 & 0.432 & 0.434 \\
\hline
\end{tabular}

This table reports the results of the multivariate analysis of relations between LN(MARKET-TO-BOOK) and I_FIRM controlling for firm over-performance. The sample consists of 2240 observations on Italian nonfinancial firms traded on the MSE over the period 1999-2011. All variables are defined as in the appendix. t-statistics based on standard errors clustered by firm and year are reported in parenthesis. ${ }^{* * *}$, **, and * indicate statistical significance at the $1 \%, 5 \%$, and $10 \%$ levels, respectively.

\section{Firm earnings quality and the Local Home Bias}

In this section, we test the significance of the relations between LN(MARKET-TO-BOOK) and I_FIRM across low and high earnings quality firms (LOW EQ vs. HIGH EQ). We expect the relation of I_FIRM with MARKET-TO-BOOK to be negative, and higher in over- rather than in under-performing firms (i.e., $\gamma_{1}<\gamma_{3} ; \gamma_{2}<\gamma_{4}$ ). In addition, we predict the effect of I_FIRM to be higher in LOW EQ than in HIGH EQ (i.e., $\gamma_{1}<\gamma_{2} ; \gamma_{3}<\gamma_{4}$ ), and the discrepancy of the effects to increase with firm over-performance, i.e. shifting from $1 y A L P H A^{+}$to $3 y A L P H A^{+}$. Table 3 reports the results when market measures of EQ are considered: models 1-3 are with EQ1 MARKET, models 4-6 are with EQ2 MARKET, while models 7-9 use EQ3 MARKET.

In all models and for all measures of EQ, the relation between I_FIRM and MARKET-TO-BOOK is negative and, in most cases, statistically significant. Consistent with previous findings (cf. Table 2), the effect of I_FIRM on MARKET-TO-BOOK is always higher in over- rather than in under-performing firms (e.g., model 6: $\gamma_{1}=-0.232, p$-value $<0.01 ; \gamma_{3}=-0.183, p$ value $<0.01 ; F$-Test $\gamma_{1}=\gamma_{3}=5.97, p$-value $<0.05$ ). In addition, the effect of I_FIRM is higher in LOW EQ than in HIGH EQ firms (e.g., model 6, 3yALPHA ${ }^{+}=1: \gamma_{1}=-0.232, p$-value $<0.01 ; \gamma_{2}=-0.147, p$-value $<0.01 ; F$-Test $\gamma_{1}=\gamma_{2}=7.98, p$-value $<0.01$; $3 y$ SLPHA $^{-}=1: \gamma_{3}=-0.183, p$-value $<0.01 ; \gamma_{4}=-0.069, p$-value $>0.10 ; F$-Test $\gamma_{3}=\gamma_{4}=11.22, p$-value $<0.01$ ), meaning that, the more the issuing firm is isolated from the other listed firms, the more the opaque firm trades at a premium compared to the firm which is fully compliant with accounting principles. As predicted, the difference in market values in LOW EQ and HIGH EQ firms increases with firm future profitability. For instance, when EQ is measured through EQ2 MARKET, the 
Table 3

The Local Home Bias and the earnings quality using market measures.

\begin{tabular}{|c|c|c|c|c|c|c|c|c|c|c|}
\hline \multirow{3}{*}{$\begin{array}{l}\text { Dependent variable } \\
\text { MARKET EQ proxy } \\
\text { Independent variables }\end{array}$} & & \multicolumn{9}{|c|}{ LN(MARKET-TO-BOOK) } \\
\hline & & \multicolumn{3}{|l|}{ EQ1 } & \multicolumn{3}{|l|}{ EQ2 } & \multicolumn{3}{|l|}{ EQ3 } \\
\hline & & (1) & $(2)$ & (3) & $(4)$ & $(5)$ & (6) & $(7)$ & (8) & (9) \\
\hline Constant & & $\begin{array}{r}0.312 \\
(0.72)\end{array}$ & $\begin{array}{c}0.314 \\
(0.73)\end{array}$ & $\begin{array}{c}0.278 \\
(0.64)\end{array}$ & $\begin{array}{c}0.325 \\
(0.72)\end{array}$ & $\begin{array}{c}0.322 \\
(0.71)\end{array}$ & $\begin{array}{c}0.301 \\
(0.67)\end{array}$ & $\begin{array}{r}0.327 \\
(0.69)\end{array}$ & $\begin{array}{c}0.349 \\
(0.74)\end{array}$ & $\begin{array}{c}0.330 \\
(0.70)\end{array}$ \\
\hline I_FIRM ${ }^{*} 1 y A L P H A^{+*}$ LOW EQ & $\gamma_{1}$ & $\begin{array}{l}-0.113^{* *} \\
(-2.12)\end{array}$ & & & $\begin{array}{l}-0.208^{\text {**** }} \\
(-5.24)\end{array}$ & & & $\begin{array}{l}-0.126^{* * *} \\
(-2.50)\end{array}$ & & \\
\hline I_FIRM* $1 y A L P H A^{+*} H I G H E Q$ & $\gamma_{2}$ & $\begin{array}{l}-0.090^{*} \\
(-1.86)\end{array}$ & & & $\begin{array}{l}-0.093^{* *} \\
(-2.00)\end{array}$ & & & $\begin{array}{l}-0.094^{*} \\
(-1.86)\end{array}$ & & \\
\hline I_FIRM ${ }^{*} 1 y A L P H A^{-*}$ LOW EQ & $\gamma_{3}$ & $\begin{array}{l}-0.089 \\
(-1.48)\end{array}$ & & & $\begin{array}{l}-0.174^{* * *} \\
(-3.03)\end{array}$ & & & $\begin{array}{l}-0.098^{*} \\
(-1.96)\end{array}$ & & \\
\hline I_FIRM ${ }^{*} 1 y A L P H A^{-*} H I G H E Q$ & $\gamma_{4}$ & $\begin{array}{l}-0.078 \\
(-1.17)\end{array}$ & & & $\begin{array}{l}-0.078 \\
(-1.16)\end{array}$ & & & $\begin{array}{l}-0.067 \\
(-1.14)\end{array}$ & & \\
\hline $1 y A L P H A^{+}$ & & $\begin{array}{r}-0.071 \\
(-0.71)\end{array}$ & & & $\begin{array}{l}-0.071 \\
(-0.71)\end{array}$ & & & $\begin{array}{l}-0.030 \\
(-0.28)\end{array}$ & & \\
\hline I_FIRM ${ }^{*} 2 y A L P H A^{+*} L O W E Q$ & $\gamma_{1}$ & & $\begin{array}{l}-0.125^{* *} \\
(-2.18)\end{array}$ & & & $\begin{array}{l}-0.197^{\text {**** }} \\
(-3.87)\end{array}$ & & & $\begin{array}{l}-0.135^{* *} \\
(-2.39)\end{array}$ & \\
\hline$I_{-}$FIRM ${ }^{*} 2 y A L P H A^{+}{ }^{*} H I G H E Q$ & $\gamma_{2}$ & & $\begin{array}{l}-0.106^{* *} \\
(-2.09)\end{array}$ & & & $\begin{array}{l}-0.109^{* * *} \\
(-2.20)\end{array}$ & & & $\begin{array}{l}-0.112^{* *} \\
(-2.19)\end{array}$ & \\
\hline I_FIRM* $2 y A L P H A^{-*} L O W E Q$ & $\gamma_{3}$ & & $\begin{array}{l}-0.090 \\
(-1.56)\end{array}$ & & & $\begin{array}{l}-0.200^{\text {**** }} \\
(-3.78)\end{array}$ & & & $\begin{array}{l}-0.106^{* *} \\
(-2.13)\end{array}$ & \\
\hline I_FIRM ${ }^{*} 2 y A L P H A^{-*} H I G H E Q$ & $\gamma_{4}$ & & $\begin{array}{l}-0.073 \\
(-1.51)\end{array}$ & & & $\begin{array}{r}-0.077 \\
(-1.61)\end{array}$ & & & $\begin{array}{l}-0.061 \\
(-1.08)\end{array}$ & \\
\hline $2 y A L P H A^{+}$ & & & $\begin{array}{l}-0.019 \\
(-0.14)\end{array}$ & & & $\begin{array}{l}-0.034 \\
(-0.25)\end{array}$ & & & $\begin{array}{c}0.009 \\
(0.06)\end{array}$ & \\
\hline I_FIRM*3yALPHA ${ }^{+*} L O W E Q$ & $\gamma_{1}$ & & & $\begin{array}{l}-0.162^{* * *} \\
(-2.79)\end{array}$ & & & $\begin{array}{l}-0.232^{* * *} \\
(-4.12)\end{array}$ & & & $\begin{array}{l}-0.161^{* * *} \\
(-2.72)\end{array}$ \\
\hline I_FIRM*3yALPHA ${ }^{+*} H I G H E Q$ & $\gamma_{2}$ & & & $\begin{array}{l}-0.142^{* *} \\
(-2.53)\end{array}$ & & & $\begin{array}{l}-0.147^{* * *} \\
(-2.77)\end{array}$ & & & $\begin{array}{l}-0.145^{\text {**** }} \\
(-2.80)\end{array}$ \\
\hline I_FIRM*3yALPHA-*LOW EQ & $\gamma_{3}$ & & & $\begin{array}{l}-0.085 \\
(-1.49)\end{array}$ & & & $\begin{array}{l}-0.183^{* * *} \\
(-4.01)\end{array}$ & & & $\begin{array}{l}-0.102^{* *} \\
(-2.12)\end{array}$ \\
\hline I_FIRM*3yALPHA ${ }^{-*} H I G H E Q$ & $\gamma_{4}$ & & & $\begin{array}{l}-0.065 \\
(-1.37)\end{array}$ & & & $\begin{array}{l}-0.069 \\
(-1.47)\end{array}$ & & & $\begin{array}{l}-0.055 \\
(-1.00)\end{array}$ \\
\hline $3 y A L P H A^{+}$ & & & & $\begin{array}{r}0.072 \\
(0.44)\end{array}$ & & & $\begin{array}{r}0.073 \\
(0.45)\end{array}$ & & & $\begin{array}{c}0.083 \\
(0.53)\end{array}$ \\
\hline LOW EQ & & $\begin{array}{l}-0.111 \\
(-0.71)\end{array}$ & $\begin{array}{l}-0.107 \\
(-0.69)\end{array}$ & $\begin{array}{l}-0.117 \\
(-0.75)\end{array}$ & $\begin{array}{l}-0.126 \\
(-0.77)\end{array}$ & $\begin{array}{l}-0.133 \\
(-0.86)\end{array}$ & $\begin{array}{l}-0.127 \\
(-0.78)\end{array}$ & $\begin{array}{l}-0.081 \\
(-0.80)\end{array}$ & $\begin{array}{l}-0.091 \\
(-0.96)\end{array}$ & $\begin{array}{l}-0.098 \\
(-0.97)\end{array}$ \\
\hline I_INCOME & & $\begin{array}{l}0.439^{* * * *} \\
(2.60)\end{array}$ & $\begin{array}{l}0.429^{* *} \\
(2.52)\end{array}$ & $\begin{array}{l}0.426^{* *} \\
(2.50)\end{array}$ & $\begin{array}{l}0.444^{* * * *} \\
(2.66)\end{array}$ & $\begin{array}{l}0.438^{* * * *} \\
(2.60)\end{array}$ & $\begin{array}{l}0.432^{* *} \\
(2.56)\end{array}$ & $\begin{array}{l}0.420^{* *} \\
(2.38)\end{array}$ & $\begin{array}{l}0.407^{\text {*** }} \\
(2.29)\end{array}$ & $\begin{array}{l}0.404^{* * *} \\
(2.27)\end{array}$ \\
\hline$R O E$ & & $\begin{array}{l}0.361^{* *} \\
(2.11)\end{array}$ & $\begin{array}{c}0.343^{*} \\
(1.94)\end{array}$ & $\begin{array}{c}0.339 * \\
(1.89)\end{array}$ & $\begin{array}{l}0.350^{* *} \\
(2.15)\end{array}$ & $\begin{array}{l}0.335^{* *} \\
(1.97)\end{array}$ & $\begin{array}{c}0.332^{*} \\
(1.94)\end{array}$ & $\begin{array}{c}0.356^{*} \\
(1.89)\end{array}$ & $\begin{array}{c}0.346^{*} \\
(1.78)\end{array}$ & $\begin{array}{c}0.338^{*} \\
(1.73)\end{array}$ \\
\hline$R E D-T O-S A L E S$ & & $\begin{array}{c}1.895 \\
(1.46)\end{array}$ & $\begin{array}{c}1.866 \\
(1.47)\end{array}$ & $\begin{array}{c}1.754 \\
(1.38)\end{array}$ & $\begin{array}{r}1.749 \\
(1.33)\end{array}$ & $\begin{array}{r}1.714 \\
(1.36)\end{array}$ & $\begin{array}{r}1.612 \\
(1.27)\end{array}$ & $\begin{array}{c}1.446 \\
(1.02)\end{array}$ & $\begin{array}{r}1.355 \\
(0.98)\end{array}$ & $\begin{array}{c}1.254 \\
(0.92)\end{array}$ \\
\hline$L N(1+F I R M ~ S I Z E)$ & & $\begin{array}{l}-0.068^{* *} \\
(-2.04)\end{array}$ & $\begin{array}{l}-0.067^{* *} \\
(-2.05)\end{array}$ & $\begin{array}{l}-0.066^{* *} \\
(-2.02)\end{array}$ & $\begin{array}{l}-0.068^{* *} \\
(-2.02)\end{array}$ & $\begin{array}{l}-0.066^{* *} \\
(-2.01)\end{array}$ & $\begin{array}{l}-0.066^{* *} \\
(-2.02)\end{array}$ & $\begin{array}{c}-0.067^{*} \\
(-1.89)\end{array}$ & $\begin{array}{l}-0.067^{*} \\
(-1.93)\end{array}$ & $\begin{array}{l}-0.067^{*} \\
(-1.91)\end{array}$ \\
\hline$L N(1+F I R M A G E)$ & & $\begin{array}{l}-0.101^{* * *} \\
(-3.32)\end{array}$ & $\begin{array}{l}-0.100^{* * *} \\
(-3.28)\end{array}$ & $\begin{array}{l}-0.098^{\text {**** }} \\
(-3.26)\end{array}$ & $\begin{array}{l}-0.099^{* * * *} \\
(-3.22)\end{array}$ & $\begin{array}{l}-0.098^{\text {**** }} \\
(-3.18)\end{array}$ & $\begin{array}{l}-0.097^{* * * *} \\
(-3.17)\end{array}$ & $\begin{array}{l}-0.099^{* * * *} \\
(-2.81)\end{array}$ & $\begin{array}{l}-0.098^{\text {**** }} \\
(-2.73)\end{array}$ & $\begin{array}{l}-0.097^{* * *} \\
(-2.75)\end{array}$ \\
\hline LN(1+PRESS COVERAGE) & & $\begin{array}{l}0.253^{\text {**** }} \\
(4.67)\end{array}$ & $\begin{array}{l}0.253^{\text {**** }} \\
(4.73)\end{array}$ & $\begin{array}{l}0.251^{\text {**** }} \\
(4.62)\end{array}$ & $\begin{array}{l}0.257^{* * *} \\
(4.74)\end{array}$ & $\begin{array}{l}0.256^{* * * *} \\
(4.77)\end{array}$ & $\begin{array}{l}0.255^{\text {**** }} \\
(4.68)\end{array}$ & $\begin{array}{l}0.262^{* * * *} \\
(4.66)\end{array}$ & $\begin{array}{l}0.261^{* * * *} \\
(4.72)\end{array}$ & $\begin{array}{l}0.260^{* * * *} \\
(4.62)\end{array}$ \\
\hline Dummy industry & & YES & YES & YES & YES & YES & YES & YES & YES & YES \\
\hline Dummy exchange segment & & YES & YES & YES & YES & YES & YES & YES & YES & YES \\
\hline Dummy year & & YES & YES & YES & YES & YES & YES & YES & YES & YES \\
\hline Number of observations & & 1229 & 1229 & 1229 & 1229 & 1229 & 1229 & 1145 & 1145 & 1145 \\
\hline $\mathrm{R}^{2}$ - adjusted & & 0.430 & 0.428 & 0.431 & 0.430 & 0.429 & 0.432 & 0.427 & 0.427 & 0.430 \\
\hline
\end{tabular}

This table reports the results of the multivariate analysis of relations between LN(MARKET-TO-BOOK) and I_FIRM controlling for firm over-performance and EQ. The sample consists of 2240 observations on Italian nonfinancial firms traded on the MSE over the period 1999-2011. All variables are defined as in the appendix. t-statistics based on standard errors clustered by firm and year are reported in parenthesis. ${ }^{* * *},{ }^{* *}$, and * indicate statistical significance at the $1 \%, 5 \%$, and $10 \%$ levels, respectively.

effect of I_FIRM in LOW EQ firms with positive ALPHA in each of the next 3 years is about $12 \%$ higher than in LOW EQ firms over-performing in the prospective year only. When EQ1 MARKET or EQ3 MARKET are used for EQ the differential effect for opaque firms rises up to $43 \%$ and $28 \%$, respectively.

Table 4 reports results when discretionary accruals are used to proxy EQ: models 1-3 are with EQ1 ACCOUNTING, while models 4-6 use EQ2 ACCOUNTING.

When EQ is measured through EQ2 ACCOUNTING, results are generally comparable to the previous ones even though some differences can be detected. In fact, the relation between I_FIRM and MARKET-TO-BOOK is negative and statistically significant 
Table 4

The Local Home Bias and the earnings quality using discretionary accruals.

\begin{tabular}{|c|c|c|c|c|c|c|c|}
\hline \multirow{3}{*}{$\begin{array}{l}\text { Dependent variable } \\
\text { ACCOUNTING EQ proxy } \\
\text { Independent variables }\end{array}$} & & \multicolumn{6}{|c|}{ LN(MARKET-TO-BOOK) } \\
\hline & & \multicolumn{3}{|l|}{ EQ1 } & \multicolumn{3}{|l|}{ EQ2 } \\
\hline & & (1) & $(2)$ & (3) & $(4)$ & (5) & (6) \\
\hline Constant & & $\begin{array}{r}0.587 \\
(1.02)\end{array}$ & $\begin{array}{c}0.592 \\
(1.02)\end{array}$ & $\begin{array}{c}0.569 \\
(1.00)\end{array}$ & $\begin{array}{r}0.357 \\
(0.51)\end{array}$ & $\begin{array}{c}0.305 \\
(0.43)\end{array}$ & $\begin{array}{c}0.300 \\
(0.43)\end{array}$ \\
\hline I_FIRM ${ }^{*} 1 y A L P H A^{+*} L O W$ EQ & $\gamma_{1}$ & $\begin{array}{c}-0.104^{*} \\
(-1.88)\end{array}$ & & & $\begin{array}{l}-0.159^{* *} \\
(-2.31)\end{array}$ & & \\
\hline I_FIRM*1yALPHA ${ }^{+*} H I G H$ EQ & $\gamma_{2}$ & $\begin{array}{c}-0.084 \\
(-1.37)\end{array}$ & & & $\begin{array}{l}-0.066 \\
(-1.11)\end{array}$ & & \\
\hline I_FIRM*1yALPHA ${ }^{-*} L O W$ EQ & $\gamma_{3}$ & $\begin{array}{l}-0.096 \\
(-1.42)\end{array}$ & & & $\begin{array}{l}-0.135^{* *} \\
(-2.49)\end{array}$ & & \\
\hline I_FIRM*1yALPHA ${ }^{-*} H I G H$ EQ & $\gamma_{4}$ & $\begin{array}{l}-0.088 \\
(-1.52)\end{array}$ & & & $\begin{array}{l}-0.071 \\
(-1.14)\end{array}$ & & \\
\hline $1 y A L P H A^{+}$ & & $\begin{array}{c}-0.111 \\
(-0.85)\end{array}$ & & & $\begin{array}{r}-0.116 \\
(-0.65)\end{array}$ & & \\
\hline$I_{-}$IRM $^{*} 2 y A L P H A^{+*} L O W$ EQ & $\gamma_{1}$ & & $\begin{array}{c}-0.109 * \\
(-1.76)\end{array}$ & & & $\begin{array}{l}-0.167^{\text {**** }} \\
(-2.87)\end{array}$ & \\
\hline I_FIRM ${ }^{*} 2 y A L P H A^{+*} H I G H E Q$ & $\gamma_{2}$ & & $\begin{array}{l}-0.076 \\
(-1.17)\end{array}$ & & & $\begin{array}{r}-0.071 \\
(-1.09)\end{array}$ & \\
\hline I_FIRM ${ }^{*} 2 y A L P H A^{-*} L O W E Q$ & $\gamma_{3}$ & & $\begin{array}{l}-0.075 \\
(-1.16)\end{array}$ & & & $\begin{array}{l}-0.126^{* *} \\
(-2.04)\end{array}$ & \\
\hline I_FIRM*2yALPHA ${ }^{-*} H I G H E Q$ & $\gamma_{4}$ & & $\begin{array}{c}-0.086 \\
(-1.48)\end{array}$ & & & $\begin{array}{l}-0.070 \\
(-1.16)\end{array}$ & \\
\hline $2 y A L P H A^{+}$ & & & $\begin{array}{r}-0.170 \\
(-1.09)\end{array}$ & & & $\begin{array}{r}-0.125 \\
(-0.56)\end{array}$ & \\
\hline I_FIRM*3yALPHA ${ }^{+*}$ LOW EQ & $\gamma_{1}$ & & & $\begin{array}{r}-0.107 \\
(-1.53)\end{array}$ & & & $\begin{array}{l}-0.178^{* * *} \\
(-2.85)\end{array}$ \\
\hline I_FIRM*3yALPHA ${ }^{+*} H I G H$ EQ & $\gamma_{2}$ & & & $\begin{array}{r}-0.110 \\
(-1.62)\end{array}$ & & & $\begin{array}{c}-0.110^{*} \\
(-1.73)\end{array}$ \\
\hline I_FIRM*3yALPHA ${ }^{-*} L O W E Q$ & $\gamma_{3}$ & & & $\begin{array}{c}-0.094 \\
(-1.52)\end{array}$ & & & $\begin{array}{l}-0.153^{* * *} \\
(-2.84)\end{array}$ \\
\hline I_FIRM*3yALPHA ${ }^{-*} H I G H$ EQ & $\gamma_{4}$ & & & $\begin{array}{r}-0.075 \\
(-1.29)\end{array}$ & & & $\begin{array}{l}-0.059 \\
(-0.98)\end{array}$ \\
\hline $3 y A L P H A^{+}$ & & & & $\begin{array}{c}-0.039 \\
(-0.22)\end{array}$ & & & $\begin{array}{r}-0.013 \\
(-0.05)\end{array}$ \\
\hline LOW EQ & & $\begin{array}{c}-0.022 \\
(-0.22)\end{array}$ & $\begin{array}{c}-0.022 \\
(-0.22)\end{array}$ & $\begin{array}{l}-0.026 \\
(-0.26)\end{array}$ & $\begin{array}{r}-0.110 \\
(-1.14)\end{array}$ & $\begin{array}{r}-0.101 \\
(-1.00)\end{array}$ & $\begin{array}{r}-0.104 \\
(-1.09)\end{array}$ \\
\hline I_INCOME & & $\begin{array}{c}0.316^{*} \\
(1.72)\end{array}$ & $\begin{array}{r}0.301 \\
(1.63)\end{array}$ & $\begin{array}{r}0.295 \\
(1.58)\end{array}$ & $\begin{array}{l}0.385^{* *} \\
(2.08)\end{array}$ & $\begin{array}{l}0.382^{* *} \\
(2.08)\end{array}$ & $\begin{array}{c}0.372^{* *} \\
(1.99)\end{array}$ \\
\hline$R O E$ & & $\begin{array}{r}0.196 \\
(1.04)\end{array}$ & $\begin{array}{r}0.188 \\
(0.97)\end{array}$ & $\begin{array}{r}0.176 \\
(0.90)\end{array}$ & $\begin{array}{r}0.169 \\
(0.88)\end{array}$ & $\begin{array}{r}0.163 \\
(0.85)\end{array}$ & $\begin{array}{r}0.146 \\
(0.76)\end{array}$ \\
\hline$R E D-T O-S A L E S$ & & $\begin{array}{r}1.729 \\
(1.06)\end{array}$ & $\begin{array}{c}1.704 \\
(1.10)\end{array}$ & $\begin{array}{r}1.613 \\
(1.04)\end{array}$ & $\begin{array}{c}2.083 \\
(1.20)\end{array}$ & $\begin{array}{c}2.093 \\
(1.24)\end{array}$ & $\begin{array}{c}2.029 \\
(1.19)\end{array}$ \\
\hline$L N(1+F I R M ~ S I Z E)$ & & $\begin{array}{l}-0.070^{*} \\
(-1.74)\end{array}$ & $\begin{array}{l}-0.069^{*} \\
(-1.71)\end{array}$ & $\begin{array}{l}-0.070^{*} \\
(-1.73)\end{array}$ & $\begin{array}{l}-0.070 \\
(-1.53)\end{array}$ & $\begin{array}{l}-0.065 \\
(-1.37)\end{array}$ & $\begin{array}{c}-0.068 \\
(-1.49)\end{array}$ \\
\hline$L N(1+F I R M A G E)$ & & $\begin{array}{l}-0.076^{* *} \\
(-2.07)\end{array}$ & $\begin{array}{l}-0.074^{* *} \\
(-2.00)\end{array}$ & $\begin{array}{l}-0.075^{* *} \\
(-1.97)\end{array}$ & $\begin{array}{l}-0.079^{* *} \\
(-2.41)\end{array}$ & $\begin{array}{l}-0.079^{* *} \\
(-2.37)\end{array}$ & $\begin{array}{l}-0.079^{\text {** }} \\
(-2.32)\end{array}$ \\
\hline LN $(1+P R E S S$ COVERAGE $)$ & & $\begin{array}{l}0.243^{\text {**** }} \\
(3.65)\end{array}$ & $\begin{array}{l}0.246^{* * *} \\
(3.70)\end{array}$ & $\begin{array}{l}0.244^{* * * *} \\
(3.60)\end{array}$ & $\begin{array}{l}0.272^{* * * *} \\
(3.58)\end{array}$ & $\begin{array}{l}0.270^{* * * *} \\
(3.57)\end{array}$ & $\begin{array}{l}0.271^{\text {*** }} \\
(3.54)\end{array}$ \\
\hline Dummy industry & & YES & YES & YES & YES & YES & YES \\
\hline Dummy exchange segment & & YES & YES & YES & YES & YES & YES \\
\hline Dummy year & & YES & YES & YES & YES & YES & YES \\
\hline Number of observations & & 725 & 725 & 725 & 565 & 565 & 565 \\
\hline $\mathrm{R}^{2}$ - adjusted & & 0.419 & 0.42 & 0.417 & 0.42 & 0.421 & 0.421 \\
\hline
\end{tabular}

This table reports the results of the multivariate analysis of relations between LN(MARKET-TO-BOOK) and I_FIRM controlling for firm over-performance and EQ. The sample consists of 2240 observations on Italian nonfinancial firms traded on the MSE over the period 1999-2011. All variables are defined as in the appendix. t-statistics based on standard errors clustered by firm and year are reported in parenthesis. ${ }^{* * *},{ }^{* *}$, and $*$ indicate statistical significance at the $1 \%, 5 \%$, and $10 \%$ levels, respectively.

in LOW EQ firms. Yet, this relation is almost never significant when HIGH EQ firms are considered. Most importantly, the effect of I_FIRM is still higher in LOW EQ than in HIGH EQ firms (e.g., model 6, $3 y A L P H A^{+}=1: \gamma_{1}=-0.178, p$-value $<0.01$; $\gamma_{2}=-0.110, p$-value $<0.10 ; F$-Test $\gamma_{1}=\gamma_{2}=3.61, p$-value $<0.05 ; 3 y A L P H A^{-}=1: \gamma_{3}=-0.153, p$-value $<0.01 ; \gamma_{4}=-0.059, p$ value $>0.10 ; F$-Test $\gamma_{3}=\gamma_{4}=9.08, p$-value $<0.01$ ), and the magnitude of the effect increases with firm future performance. On the other hand, when EQ is measured through EQ1 ACCOUNTING, the relation between I_FIRM and MARKET-TO-BOOK is almost never significant. 
Previous findings suggest that the firm EQ affects investor preference for local stocks: poor disclosure increases the value of the information available just locally, which local investors exploit by investing in stocks with positive future risk-adjusted performance. Economically, a measure of the value of the information locally available and not conveyed to the market through the accounting disclosure can be inferred by considering the average sampled over-performing and opaque firm, for which MARKET-TO-BOOK is 1.65 , I_FIRM is $3.09,3 y A L P H A^{+}$is 1 and LOW EQ is 1 . When EQ is measured by EQ2 MARKET our findings imply that, all other things being equal, 1.24 of MARKET-TO-BOOK is attributable to I_FIRM. The same estimate for the average sampled over-performing but non-opaque firm $(H I G H E Q=1)$ is about 0.95, meaning that the MARKET-TO$B O O K$ of opaque and isolated firms is up to $29 \%$ higher than the MARKET-TO-BOOK of isolated firms with full information disclosure. This difference in value is entirely attributable to the information that is only available to and therefore exploited by local investors.

\section{Conclusions}

The investor preference for local stocks provides a quasi-experimental setting to test whether the market rewards firms that comply with accounting principles. The Local Home Bias disentangles local from non-local investors and isolates the locally available information from the publicly available information. Research acknowledges that superior information at a local level drives the over-investment in local equity, which in turn boosts corporate market values in isolated firms. We argue that the value of the information available locally drops with the firm earnings quality (i.e., with the disclosure of accounting information). In fact, the lower the firm earnings quality, the higher the advantage to local investors who then invest in local stocks with positive future risk-adjusted performance.

Consistent with our conjecture, we find that the more a firm is isolated from the other listed firms, the more the overperforming firm trades at a premium compared to the under-performing firm, and this effect becomes stronger as the over-performance period increases. Furthermore, we find the higher the firm isolation, the more a low earnings quality firm trades at a premium compared to a high earnings quality firm. We employ several different market- and accounting-based measures to proxy for the firm earnings quality, such as residual return negative skewness, negative return jumps, idiosyncratic risk, and persistency of discretionary accruals. In all cases, the pattern is unchanged meaning that local investors effectively exploit the information available at the local level. Remarkably, the value of information not conveyed to the market through the accounting disclosure is approximately $30 \%$ of the market-to-book.

Our empirical findings add to the earnings quality, asset-pricing, and Local Home Bias literature. More importantly, the financial and accounting research is enriched by results on the relation between the quality of reporting and capital market consequences. In fact, we show that compliance with accounting principles matters. Unlike prior studies supporting the existence of a positive relation (e.g., Francis et al., 2005) or the lack of a relation (e.g., Core et al., 2008) between accruals quality and corporate market value, we consider the local perspective and find a negative relation between earnings quality and investor trading pattern. Overall, our results depict investors as a group which is heterogeneous in evaluating a firm's earnings quality: while non-local investors are sensitive to the quality of the accounting information, local and betterinformed investors are not. Local investors seek firms with partial disclosure in order to exploit the superior information they possess by investing in positive alphas' local stocks, and the firm earnings quality defines the value of the information advantage local investors have over the rest of the market. We also contribute to the Local Home Bias literature by showing that the bias of investors to invest locally is leveraged by the firm opacity. Our findings are consistent with recent studies highlighting the increase of investors' biases and their preference for local equity during periods of higher uncertainty at market-level (e.g., Kumar, 2009). We add to this literature and test this issue considering a different perspective: uncertainty defined at firm-level rather than at market-level. Ultimately, our results support and help detect the persistence of investors' biases also in periods with less market uncertainty, especially toward firms not compliant with general accounting principles. Finally, our findings also provide an original point of view to the literature addressing the value of firm disclosure as a signal of firm quality (e.g., Al Jifri and Citron, 2009). In fact, we suggest firms might voluntarily choose not to improve reporting quality due to local investor recognition of their fair value and the value enhancing Local Home Bias effect. We believe there is ample room for future research.

\section{Acknowledgements}

For their comments and suggestions, we would like to thank Roberta Adami, Hakan Aygoren, Charles Baden-Fuller, Marco Bigelli, Amit Goyal, Luzy Hail, Henry Lahr, Bruce N. Lehmann, Martens Martin, Ike Mathur, Jennifer Monroe, Sandro Sandri, Haim Shalit as well as the participants at the Multinational Finance Society Annual Conference (June 2010) and the European Financial Management Association Annual Conference (June 2012). The views expressed herein are those of the authors, and we alone bear responsibility for any mistakes and inaccuracies.

\section{Appendix}

Table A.1. 
Table A.1

Variable definitions.

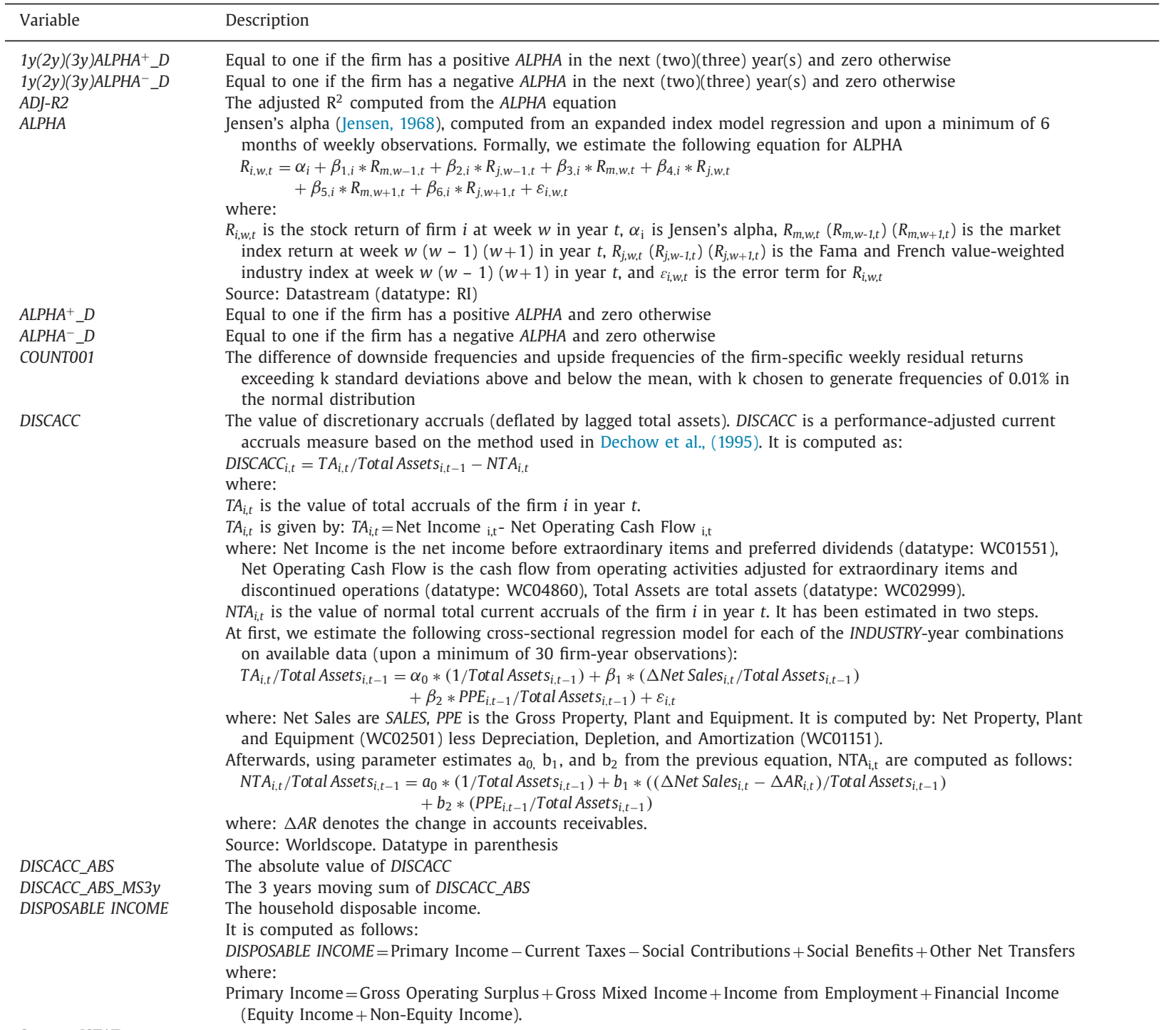

Source: ISTAT

DISTANCE

The shortest spherical distance between two points on the Earth's surface in kilometers.

Formally, let $\left(\theta_{\mathrm{s}}, \lambda_{\mathrm{s}}\right)$ and $\left(\theta_{\mathrm{f}}, \lambda_{\mathrm{f}}\right)$ be the geographical latitude and longitude of two points, a base standpoint $\mathrm{S}$ and the destination fore point $\mathrm{F}$ respectively. The DISTANCE $d_{s f}$ between $\mathrm{S}$ and $\mathrm{F}$ is computed as:

$d_{s, f}=\arccos \left\{\cos \left(\operatorname{lon}_{s}-\operatorname{lon}_{f}\right) * \cos \left(\operatorname{lat}_{s}\right) * \cos \left(\operatorname{lat}_{f}\right)+\sin \left(\operatorname{lat}_{s}\right) * \sin \left(\operatorname{lat}_{f}\right)\right\} * 2 \pi \mathrm{r} / 360$

where: $r$ is the radius of the earth $(\approx 6378 \mathrm{~km})$

EQUITY BOOK VALUE EQUITY MARKET VALUE

FIRM AGE

FIRM SIZE

HighEQ D

Book value of common equity. Source: Worldscope (datatype: WC03501)

Market value of common equity. Source: Worldscope (datatype: WC08001)

The number of years of a firm's life since foundation. Source: Il Calepino dell'Azionista

Total asset. Source: Worldscope (datatype: WC02999)

Equal to one if the firm EQ is below the cross-sectional median and zero otherwise

The Johnson and Zimmer index of dispersion.

Formally, given the two-dimensional Euclidean space $\mathrm{E}^{2}$, let the generic point $i$ and a sample of $r$ random points in $\mathrm{E}^{2}$, all individuated by the latitude and longitude geographical coordinates, the Johnson and Zimmer dispersion index I for the point $i$ is computed as:

$I=\frac{(r+1) \sum_{r=1}^{r} \sum_{r \neq i}^{r}\left(d_{i, r}^{4}\right)}{\left[\sum_{r=1}^{r} \sum_{r \neq i}^{r}\left(d_{i, r}^{2}\right)\right]^{2}}$

where: $\mathrm{d}_{\mathrm{i}, \mathrm{r}}$ is the DISTANCE between the point $i$ and each of the $r$-points. 
Table A.1 (continued)

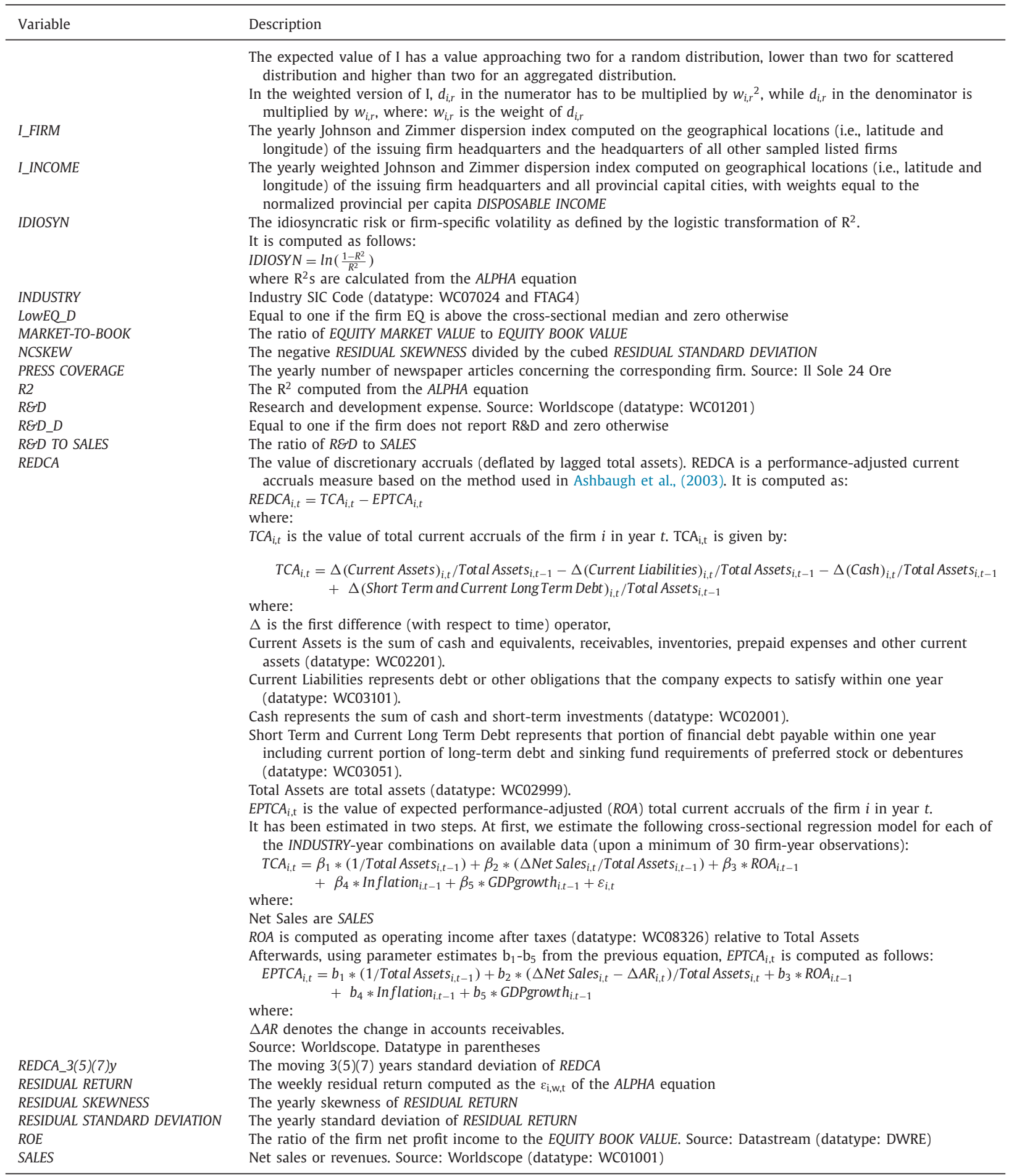

\section{References}

Aabo, T., Pantzalis, C., Sørensen, M.S., 2013. Game hoarding in Europe: stock-price consequences of local bias? Eur. J. Financ. 19 , 318-335.

Al Jifri, K., Citron, D., 2009. The value-relevance of financial statement recognition versus note disclosure: evidence from goodwill accounting. Eur. Account. Rev. 18, 123-140.

Arnold, P.J., 2009. Global financial crisis: the challenge to accounting research. Account. Org. Soc. 34, 803-809.

Ashbaugh, H., LaFond, R., Mayhew, B.W., 2003. Do nonaudit services compromise auditor independence? Further evidence. Account. Rev. 78, 611-639. 
Bagella, M., Becchetti, L., Carpentieri, A., 2000. 'The first shall be last'. Size and value strategy premia at the London Stock Exchange. J. Bank. Financ. 24, 893-919.

Barth, M.E., Landsman, W.R., 2011. How did financial reporting contribute to the financial crisis? Eur. Account. Rev. $19,399-423$.

Baschieri, G., Carosi, A., Mengoli, S., 2015. Local IPOs, local delistings, and the firm location premium. J. Bank. Financ. 53, 67-83.

Bertinetti, G.S., Mantovani, G.M., 2012. The information risk in the latest crisis: a driver or a driven factor for global financial markets equilibrium? J. Mod. Account. Auditing 8, 702-732.

Bigelli, M., Mengoli, S., 2011. Self-expropriation versus self-interest in dual-class voting: The pirelli case study. Financ. Manage. 40, 677-699.

Bhattacharya, U., Daouk, H., Welker, M., 2003. The world price of earnings opacity. Account. Rev. 78, 641-678.

Birz, G., Lott Jr., J.R., 2011. The effect of macroeconomic news on stock returns: new evidence from newspaper coverage. J. Bank. Financ. 35, 2791-2800.

Chaney, P.K., Faccio, M., Parsley, D., 2011. The quality of accounting information in politically connected firms. J. Account. Econ. 51, 58-76.

Chan, K., Chan, L.K.C., Jegadeesh, N., Lakonishok, J., 2006. Earnings quality and stock returns. J. Bus. 79, 1041-1082.

Chan, L.K.C., Lakonishok, J., Sougiannis, T., 2001. The stock market valuation of research and development expenditures. J. Financ. 56, $2431-2456$.

Chen, J., Hong, H., Stein, J.C., 2001. Forecasting crashes: trading volume, past returns, and conditional skewness in stock prices. J. Financ. Econ. 61, 345-381.

Christensen, P.O., Frimor, H., Şabac, F., 2013. The stewardship role of analyst forecasts, and discretionary versus non-discretionary accruals. Eur. Account. Rev. 22, 257-296.

Chung, H., Sheu, H.-J., Wang, J.-L., 2009. Do firms' earnings management practices affect their equity liquidity? Financ. Res. Lett. 6, $152-158$.

Core, J.E., Guay, W.R., Verdi, R., 2008. Is accruals quality a priced risk factor? J. Account. Econ. 46, 2-22.

Coval, J.D., Moskowitz, T.J., 1999. Home bias at home: local equity preference in domestic portfolios. J. Financ. 54, $2045-2073$.

Coval, J.D., Moskowitz, T.J., 2001. The geography of investment: informed trading and asset prices. J. Polit. Econ. 109, 811-841.

Cumming, D., Dai, N., 2010. Local bias in venture capital investments. J. Empir. Financ. 17, 362-380.

Cumming, D., Johan, S.A., 2006. Provincial preferences in private equity. Financ. Markets Portfolio Manage. 20, 369-398.

Cumming, D., Zambelli, S., 2013. Private equity performance under extreme regulation. J. Bank. Financ. 37, $1508-1523$.

Daniel, K.D., Hirshleifer, D., Subrahmanyam, A., 1998. Investor psychology and security market under- and overreactions. J. Financ. 53, $1839-1885$.

Daniel, K.D., Hirshleifer, D., Subrahmanyam, A., 2001. Overconfidence, arbitrage, and equilibrium asset pricing. J. Financ. 56, $921-965$.

Dechow, P.M., Ge, W., Schrand, C., 2010. Understanding earnings quality: a review of the proxies, their determinants and their consequences. J. Account. Econ. 50, 344-401.

Dechow, P.M., Sloan, R.G., Sweeney, A.P., 1995. Detecting earnings management. Account. Rev. 70, 193-225.

Ecker, F., Francis, J., Olsson, P., Schipper, K., 2013. Estimation sample selection for discretionary accruals models. J. Account. Econ. 56, $190-211$.

Francis, J., LaFond, R., Olsson, P., Schipper, K., 2005. The market pricing of accruals quality. J. Account. Econ. 39, $295-327$.

Grinblatt, M., Keloharju, M., 2001. How distance, language, and culture influence stockholdings and trades. J. Financ. 56, $1053-1073$.

Hall, B.H., Oriani, R., 2006. Does the market value R\&D investment by European firms? Evidence from a panel of manufacturing firms in France, Germany, and Italy. Int. J. Ind. Organ. 24, 971-993.

Hirshleifer, D., 2001. Investor psychology and asset pricing. J. Financ. 56, 1533-1597.

Hong, H., Kubik, J.D., Stein, J.C., 2008. The only game in town: stock-price consequences of local bias. J. Financ. Econ. 90, $20-37$.

Huang, A.Y., Cheng, C.-M., 2013. Information risk and credit contagion. Financ. Res. Lett. 10, 116-123.

Huberman, G., 2001. Familiarity breeds investment. Rev. Financ. Stud. 14, 659-680.

Hutton, A.P., Marcus, A.J., Tehranian, H., 2009. Opaque financial reports, $\mathbf{R}^{2}$, and crash risk. J. Financ. Econ. $94,67-86$.

Ivković, Z., Weisbenner, S., 2005. Local does as local is: Information content of the geography of individual investors' common stock investments. J. Financ. 60, 267-306.

Jensen, M.C., 1968. The performance of mutual funds in the period 1945-1964. J. Financ. 23, 389-416.

Jin, L., Myers, S.C., 2006. $\mathrm{R}^{2}$ around the world: new theory and new tests. J. Financ. Econ. 79, $257-592$.

Johnson, R.B., Zimmer, W.J., 1985. A more powerful test for dispersion using distance measurements. Ecology 66, $1669-1675$.

Keloharju, M., Kulp, K., 1996. Market-to-book ratios, equity retention, and management ownership in Finnish initial public offerings. J. Bank. Financ. 20, 1583-1599.

Korniotis, G.M., Kumar, A., 2013a. Do portfolio distortions reflect superior information or psychological biases? J. Financ. Quant. Anal. 48 , 1-45.

Korniotis, G.M., Kumar, A., 2013b. State-level business cycles and local return predictability. J. Financ. 68, 1037-1096.

Kothari, S.P., 2001. Capital markets research in accounting. J. Account. Econ. 31, 105-231.

Kumar, A., 2009. Hard-to-value stocks, behavioral biases, and informed trading. J. Financ. Quant. Anal. 44, 1375-1401.

Lahr, H., 2014. An improved test for earnings management using kernel density estimation. Eur. Account. Rev. 23, 559-591.

Leuz, C., Nanda, D., Wysocki, P.D., 2003. Earnings management and investor protection: an international comparison. J. Financ. Econ. 69, 505-527.

Lev, B., 1989. On the usefulness of earnings and earnings research: lessons and directions from two decades of empirical research. J. Account. Res. 27, $153-192$.

Lev, B., 2003. Corporate earnings: facts and fiction. J. Econ. Perspect. 17, 27-50.

Levis, M., Muradoglu, Y.G., Vasileva, K., 2015. Home bias persistence in foreign direct investments. Eur. J. Financ. 22 (8-9), 782-802.

Mengoli, S., Pazzaglia, F., Sapienza, E., 2009. Effect of governance reforms on corporate ownership in Italy: Is it still pizza, spaghetti, and mandolino? Corp. Gov. 17, 629-645.

Morck, R., Yeung, B., Yu, W., 2000. The information content of stock markets: why do emerging markets have synchronous stock price movements? J. Financ. Econ. 58, 215-260.

Morricone, S., Oriani, R., Sobrero, M., 2009. The value relevance of intangible assets and the mandatory adoption of IFRS. SSRN working paper.

Pazzaglia, F., Mengoli, S., Sapienza, E., 2013. Earnings quality in acquired and nonacquired family firms: A socioemotional wealth perspective. Fam. Bus. Rev. $26,374-386$.

Petersen, M.A., 2009. Estimating standard errors in finance panel data sets: Comparing approaches. Rev. Financ. Stud. 22, 435-480.

Prencipe, A., 2004. Proprietary costs and determinants of voluntary segment disclosure: evidence from Italian listed companies. Eur. Account. Rev. 13, 319-340.

Shan, L., Gong, S.X., 2012. Investor sentiment and stock returns: Wenchuan earthquake. Financ. Res. Lett. 9, 36-47.

Van Dijk, M.A., 2011. Is size dead? A review of the size effect in equity returns. J. Bank. Financ. 35, 3263-3274. 